\title{
Possible Application of the Medicinal Plant Hyoscyamus albus in Phytoremediation: Excess Copper Compensates for Iron Deficiency, Depending on the Light Conditions
}

\author{
Noriko Tamari'1, Akemi Mine², Ari Sako ${ }^{3}$, Seiya Tamagawa ${ }^{2}$, Yasuhiro Tabira4, \\ Yoshie Kitamura ${ }^{1,2,3^{*}}$ \\ ${ }^{1}$ Graduate School of Science and Technology, Nagasaki University, Nagasaki, Japan \\ ${ }^{2}$ Faculty of Environmental Studies, Nagasaki University, Nagasaki, Japan \\ ${ }^{3}$ Graduate School of Fisheries and Environmental Studies, Nagasaki University, Nagasaki, Japan \\ ${ }^{4}$ Environmental Management Center, Nagasaki University, Nagasaki, Japan \\ Email: ${ }^{*}$ k-yoshie@nagasaki-u.ac.jp
}

Received 19 October 2014; revised 18 November 2014; accepted 28 November 2014

Copyright (C) 2014 by authors and Scientific Research Publishing Inc.

This work is licensed under the Creative Commons Attribution International License (CC BY).

http://creativecommons.org/licenses/by/4.0/

(c) (i) Open Access

\section{Abstract}

Seedlings of the medicinal plant Hyoscyamus albus were supplied with an excess of $\mathrm{Cu}$ to examine the possible application in phytoremediation. The seedlings were cultured in B5 medium supplied with basal $0.1 \mu \mathrm{M} C u$ and $200 \mu \mathrm{M}$ Cu under various light conditions: short day (SD); long day (LD); and continuous light (CL). In addition, the effect of supplying $200 \mu \mathrm{M} C \mathrm{Cu}$ under Fe deficiency was determined, in order to elucidate the interaction between $\mathrm{Cu}$ and Fe. Interestingly, Fe-deficiency symptoms that developed in plants grown with basic levels of $\mathrm{Cu}$ under LD almost disappeared when excess $\mathrm{Cu}$ was supplied. Plant growth mainly depended on the photo irradiation period (SD $<\mathrm{LD} C \mathrm{CL}$ ); and $200 \mu \mathrm{M}$ Cu did not inhibit growth at all when Fe was available, whereas in the absence of Fe, CL caused damage to growth. Analysis of the $\mathrm{Cu}$ and Fe contents of the plants revealed that $\mathrm{Cu}$ was distributed equally in both the aerial parts and roots, whereas most of the Fe was found in the roots; under $\mathrm{Fe}$ deficiency, $\mathrm{Cu}$ accumulation in the roots apparently increased. $\mathrm{Cu}$ was mainly distributed in the soluble fraction, which included vacuoles and the cell-wall fraction. These results provide evidence indicating that $\mathrm{H}$. albus seedlings are tolerant of $\mathrm{Cu}$ present in excess. Furthermore, excess $\mathrm{Cu}$ was able to compensate for Fe deficiency, depending on the light conditions. Continuous light inhibited this effect, probably as a result of the induction of Mn defi-

${ }^{*}$ Corresponding author. 
ciency. The possible applications of this newly discovered cuprophyte are discussed.

\title{
Keywords
}

\author{
Copper Accumulator, Medicinal Plant, Hyoscyamus albus
}

\section{Introduction}

Hyoscyamus albus (Solanaceae, white henbane) is an annual or biennial plant growing on the Continent, particularly in France and in Indian subcontinent, and used as a source of hyoscyamine, which is an important anticholinergic drug of plant origin [1]. Aside from its medicinal applications, however, the other properties of this plant have attracted little attention. Recently, we found that roots of $H$. albus continued to grow under conditions of iron (Fe) deficiency, during which they secreted riboflavin into the rhizosphere [2] [3]. Fe is an essential element for plants; however, plants face Fe deficiency in neutral and alkaline soils because ferric iron, despite being abundant in the Earth's crust, is almost insoluble and therefore unavailable to plant roots. The area affected by Fe deficiency amounts to about 30\% of global total land area [4] and the prevailing situation has deteriorated due to recent climatic changes and human activities. Therefore, tolerance to Fe deficiency is an agronomicallyuseful trait.

A potentially important aspect of Fe deficiency is its relationship to the availability and uptake of other metal ions. $\mathrm{Cu}$ is also an essential element for plants, being involved in various redox reactions, including electron transfer; however, the toxicity of excess $\mathrm{Cu}$ to organisms has been widely recognized because $\mathrm{Cu}$ produces reactive oxygen species such as hydroxyl radicals, which cause oxidative damage to lipids, proteins and DNA, resulting in cellular deterioration [5]. Some plants survive high concentrations of $\mathrm{Cu}$ by limiting their uptake and accumulation of $\mathrm{Cu}$ (denoted as excluders); whereas others, which can actively uptake and accumulate $\mathrm{Cu}$, are defined as accumulators/hyperaccumulators [6]. Plants face $\mathrm{Cu}$ excess close to $\mathrm{Cu}$ mines and in Cu-polluted areas resulting from industrial activities. It is recognized that $\mathrm{Cu}$ excess can induce Fe deficiency, depending on the form of $\mathrm{Fe}$ [5]. In addition, the tight linkage between $\mathrm{Cu}$ and $\mathrm{Fe}$ homeostasis has been well recognized [7]-[9].

In this paper, we report on the effects of $\mathrm{Cu}$ excess, in combination with Fe availability, on growth and metal accumulation in the seedlings of medicinal $H$. albus. Previously, the evaluation and comparison of $\mathrm{Cu}$ - and Cd-scavenging capabilities of in vivo- and in vitro-grown Lycopersicon esculentum revealed that the concentrations of both metals in in vivo-grown leaves were much higher than in in vitro-grown leaves [10]. In addition, plants previously reported to be $\mathrm{Cu}$-hyperaccumulators have been found to require reassessment, because most of the $\mathrm{Cu}$ detected in the aerial parts of these plants was found to be the result of $\mathrm{Cu}$ adsorption at the leaf surface [11] and could be washed out by water and detergent [12]. For this reason, before carrying out experiments on plants in the field, we have here undertaken experiments with in vitro cultures, using culture media containing known concentrations of minerals, including $\mathrm{Cu}$ and $\mathrm{Fe}$, carried out under sterile conditions to avoid indirect effects caused by microorganisms.

\section{Materials and Methods}

\subsection{Plant Materials}

Seeds of Hyoscyamus albus L. (Solanaceae) were provided by Dr. Laiq ur Rahman (CIMAP, India) and then collected from mature plants after cultivation at Nagasaki University, Japan. H. albus seedlings were germinated under sterile conditions. Seeds were treated with $70 \% \mathrm{EtOH}$ for $1 \mathrm{~min}$, followed by $1 \%$ sodium hydrochloride for $15 \mathrm{~min}$, and were then washed three times with sterile water. The seeds were placed on Petri dishes containing $0.8 \%$ agar medium and kept at $25^{\circ} \mathrm{C}$ in the dark until germination. Germinated seedlings were first placed under continuous dim light $\left(22 \mu \mathrm{mol} \cdot \mathrm{m}^{-2} \cdot \mathrm{s}^{-1}\right)$ and then, when the cotyledons had developed fully, were transferred to tubes containing Murashige and Skoog basal medium [13] (containing $100 \mu \mathrm{M} \mathrm{Fe}$ and $0.1 \mu \mathrm{M} \mathrm{Cu}$ ) supplemented with $1 \%$ sucrose and solidified with $0.1 \%$ gellan gum. After two leaves had appeared, the base (between the roots and the aerial part) of each plantlet was secured with a silicone sponge and put into a wide- 
mouth $(\$ 35 \mathrm{~mm}) 100 \mathrm{ml}$ conical flask containing $20 \mathrm{~mL}$ of liquid B5 medium [14] and three combinations of $\mathrm{Fe} / \mathrm{Cu}$ concentrations as follows: control $(100 \mu \mathrm{M} \mathrm{Fe}$ and $0.1 \mu \mathrm{M} \mathrm{Cu})($ denoted as $+\mathrm{Fe} / \mathrm{Cu} 1)$; excess $\mathrm{Cu}(100 \mu \mathrm{M}$ $\mathrm{Fe}$ and $200 \mu \mathrm{M} \mathrm{Cu})(+\mathrm{Fe} / \mathrm{Cu} 2000)$; and excess $\mathrm{Cu}$ under Fe deficiency $(0 \mu \mathrm{M} \mathrm{Fe}$ and $200 \mu \mathrm{M} \mathrm{Cu})(-\mathrm{Fe} / \mathrm{Cu} 2000)$. Fe was supplied as Fe(III)-EDTA (Doujin Co., Japan). When excess Cu was supplied, as $\mathrm{CuSO}_{4}$ (Wako Chemical, Japan), EDTANa 2 (Doujin Co., Japan) was also added at the equivalent molarity in order to avoid precipitation. Media were autoclaved at $121^{\circ} \mathrm{C}$ for $15 \mathrm{~min}$ before use. Additionally, a Mn deficiency experiment was also carried out, by omitting $\mathrm{MnSO}_{4}$ (Wako Chemical, Japan) from B5 medium as follows: control (6 $\mu \mathrm{M} \mathrm{Mn}$ and 0.1 $\mu \mathrm{M} \mathrm{Cu}) ; \mathrm{Mn}$ deficiency $(0 \mu \mathrm{M} \mathrm{Mn}$ and $0.1 \mu \mathrm{M} \mathrm{Cu})$; excess $\mathrm{Cu}$ under Mn deficiency $(0 \mu \mathrm{M} \mathrm{Mn}$ and $200 \mu \mathrm{M} \mathrm{Cu})$.

Four seedlings were selected for each treatment. The plantlets in the flasks were then incubated for $2-4$ weeks at $25^{\circ} \mathrm{C}$ on a rotary shaker at $50 \mathrm{rpm}$ in the culture room under three different light conditions (121 $\mu \mathrm{mol} \cdot \mathrm{m}^{-2} \cdot \mathrm{s}^{-1}$ ): short day (SD), $10 \mathrm{~h}$ light $-24 \mathrm{~h}$ dark; long day (LD), $16 \mathrm{~h}$ light $-8 \mathrm{~h}$ dark; continuous light (CL), $24 \mathrm{~h}$ light. In addition, continuous dim light $\left(22 \mu \mathrm{mol} \cdot \mathrm{m}^{-2} \cdot \mathrm{s}^{-1}\right)$ was also used. The cultured plants were harvested after thorough washing with distilled water, followed by blotting with filter papers.

\subsection{Growth Measurement}

Harvested plants were divided into rosette leaves (leaf blades and petioles), stems and roots. Leaf numbers were counted and leaf blade sizes (widths and lengths) and petiole and root lengths (in the case of roots, the length of the longest root) were measured using micrometer calipers. The samples were weighed (FW, fresh weight) and then dried at $50^{\circ} \mathrm{C}$ to constant weight, in order to measure dry weight (DW) and to calculate water content (\%). Since stem development was negligible during culture, stems were weighed together with petioles.

\subsection{Fractionation}

Fresh tissues (roots and aerial parts) of $H$. albus seedlings were fractionated according to the reported method [15], with some modifications. Harvested fresh materials were homogenized in pre-chilled extraction buffer containing $50 \mathrm{mM}$ Tri-HCl (pH 7.5), $250 \mathrm{mM}$ sucrose, and $10 \mathrm{mM}$ DTT. The cell wall was collected by nylon mesh filtration $(82 \mu \mathrm{m})$ under vacuum and then the filtrate was centrifuged at $880 \times \mathrm{g}$ for $15 \mathrm{~min}$, followed by $21,880 \times \mathrm{g}$ for $30 \mathrm{~min}$. The respective sedimentations were denoted as nucleus/plastid and mitochondrial fractions, according to staining with acetocarmine, iodine and TTC solutions, respectively.

\subsection{Analysis of Metal Contents}

Tissues and fractions were digested with $60 \%(\mathrm{w} / \mathrm{v}) \mathrm{HNO}_{3}$ in a microwave oven (Perkin Elmer, Multiwave) at $160^{\circ} \mathrm{C}$ for $20 \mathrm{~min}$. Heavy metal contents were determined by inductively coupled plasma-optical emission spectrometry (ICP-OES) (Horiba, Ultima 2).

\subsection{Statistical Analyses}

All results were expressed as means and sd. Statistical significance was assessed by ANOVA, followed by Dunnett's multiple comparison tests (Excel Statistics, SSRI, Tokyo, Japan).

\section{Results and Discussion}

\subsection{Effects of Cu Excess and Fe Deficiency on Seedling Growth}

Previously, we observed that $H$. albus roots were able to grow under Fe deficiency [2] [3]. In addition, the roots grew well under a range of $\mathrm{Cu}$ concentrations (from 0 to $200 \mu \mathrm{M}$ ) (unpublished data). Although an excess of $\mathrm{Cu}$ seemed to favor growth of the roots, and the roots were tolerant of Fe deficiency, no information was available concerning the behavior of whole plants. Cultured roots are usually incubated in the dark, but in order to grow intact plants, photoirradiation is necessary. Therefore, we initially investigated the responses of $H$. albus seedlings cultured in liquid nutrient medium supplied with $0.1 \mu \mathrm{M} \mathrm{Cu}$ (control) and $200 \mu \mathrm{M} \mathrm{Cu}(\mathrm{Cu}$ excess), respectively, in the presence and absence of Fe, under long day conditions (LD) for 2 weeks (Figure 1). We found that under Fe deficiency the seedlings grew, but that in comparison to control plants (Figure 1(A)), their roots showed morphological changes, such as swollen root tips and shorter branches that were of a yellow color (Figure 1(B)). In the aerial parts, the leaves showed a chlorosis-like pale yellow coloration under Fe deficiency. 

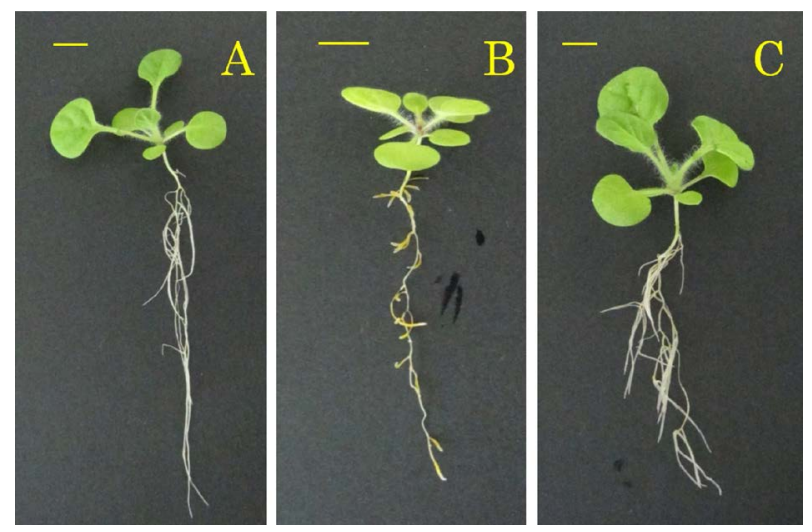

Figure 1. H. albus seedlings treated with three different $\mathrm{Cu} / \mathrm{Fe}$ concentrations. Seedlings were incubated for 2 weeks at $25^{\circ} \mathrm{C}$ on a rotary shaker at $50 \mathrm{rpm}$ in the incubator under long day (LD) conditions, $16 \mathrm{~h} \mathrm{light}\left(121 \mu \mathrm{mol} \cdot \mathrm{m}^{-2} \cdot \mathrm{s}^{-1}\right)-8 \mathrm{~h}$ dark. Photos: (A) A control plant treated with $\mathrm{CuSO}_{4}(0.1 \mu \mathrm{M})$ and Fe(III)-EDTA $(100 \mu \mathrm{M})$ in B5 basal medium; (B) A plant subjected to Fe deficiency by treatment with $\mathrm{B} 5 \mathrm{Cu}(0.1 \mu \mathrm{M})$ without $\mathrm{Fe}(-\mathrm{Fe})$; $(\mathrm{C})$ A plant subjected to $\mathrm{Cu}$ excess $(200 \mu \mathrm{M})$ in combination with Fe deficiency $(-\mathrm{Fe})$. Bars indicate $1 \mathrm{~cm}$.

On the other hand, $H$. albus seedlings were able to survive- and even grew better-under conditions of $\mathrm{Cu}$ excess. Furthermore, when the seedlings were cultured under both $\mathrm{Cu}$ excess and Fe deficiency, surprisingly the leaf color was restored and the root tips grew normally (Figure 1(C)). In comparison to control plants (Figure 1(A)), both roots and leaves developed well under $\mathrm{Cu}$ excess combined with Fe deficiency, although the primary root length seemed to be shorter (Figure 1(C)).

In considering the growth of intact plants, photo irradiation is one of the most important factors. To determine the effects of $\mathrm{Cu}$ excess on plant growth under Fe-replete and -deplete conditions, we cultured the seedlings under different light regimes, such as short day (SD), long day (LD) and continuous light (CL). After 2 and 4 weeks, the sizes (numbers of leaves, leaf sizes, and the lengths of petioles, stems and roots) and the weights (fresh weights, FW; dry weights, DW; water contents) of the harvested plants were measured (Table 1, Table 2). Under the same conditions of illumination and heavy metal availability, the values for leaf number, leaf size, petiole length, and root length all increased after 4 weeks, compared to after 2 weeks. Under Fe-replete conditions, an excess of $\mathrm{Cu}$ had no effect on plant size (Table 1). Illumination was the most important factor affecting plant size: seedlings treated with LD and CL developed better than those treated with SD for 4 weeks, although no significant difference was found between LD and CL (SD < CL LD). FW and DW showed the same response to illumination (SD < CL LD), both at the whole plant level (Table 2) and at the organ level (data not shown). The water content of in vitro-grown $H$. albus plants was around 95\%, when Fe was supplied. On the other hand, in the absence of Fe and under Cu excess, CL caused some detrimental effects to the primary root length and leaf blade size, although leaf number was not affected (Table 1). In addition, partial chlorosis of the leaves and swelling of the root tips were observed (data not shown). Furthermore, CL caused some FW reduction, but interestingly, no reduction was found on a DW basis, indicating a significant decrease in water content (to $c a .91 \%$ ) at the whole plant level (Table 2). This phenomenon was especially apparent in roots, in which the water content decreased to less than $90 \%$ (data not shown).

In general, Fe deficiency causes typical morphological changes, such as root tip swelling [16] [17] and leaf chlorosis [18] [19]; we observed such symptoms in H. albus seedlings cultured under Fe deficiency (Figure 1(B)). Although $\mathrm{Cu}$ and Fe homeostasis have been studied extensively, and diminished Fe accumulation under conditions of $\mathrm{Cu}$ excess has been reported [5] [20] [21], our observation in H. albus seedlings that typical Fe deficiency symptoms are abated under conditions of $\mathrm{Cu}$ excess (Figure $1(\mathrm{C})$ ) is, to the best of our knowledge, novel. It suggests that $\mathrm{Cu}$ is able to compensate for Fe deficiency in $H$. albus plants.

Previous reports have indicated that $\mathrm{Cu}$ excess inhibits root elongation [22] [23] and causes chlorosis in leaves [5] [20]. Our study using different light regimes revealed that under Fe-replete conditions, Cu excess (200 $\mathrm{mM}$ ) appeared not to affect growth, whereas under conditions of Fe deficiency together with $\mathrm{Cu}$ excess, damage appeared only under CL (Table 1). When H. albus seedlings were cultured without Fe under continuous dim light $\left(22 \mu \mathrm{mol} \cdot \mathrm{m}^{-2} \cdot \mathrm{s}^{-1}\right)$, no damage was found either in the roots or in the aerial parts, although plant growth was poor in comparison to that under higher irradiation $\left(121 \mu \mathrm{mol} \cdot \mathrm{m}^{-2} \cdot \mathrm{s}^{-1}\right)$ (data not shown). This suggests that it is 
Table 1. Plant development of $H$. albus seedlings after culturing under various $\mathrm{Cu} / \mathrm{Fe}$ supply and light conditions: changes in number, size and length.

\begin{tabular}{|c|c|c|c|c|c|c|c|}
\hline \multirow{2}{*}{$\begin{array}{l}\text { Culture } \\
\text { period }\end{array}$} & \multirow{2}{*}{$\begin{array}{c}\text { Light } \\
\text { condition }\end{array}$} & \multirow{2}{*}{$\mathrm{Cu} / \mathrm{Fe}$ condition } & \multirow{2}{*}{ Leaf No. } & \multicolumn{2}{|c|}{ Leaf blade size } & \multirow{2}{*}{$\begin{array}{c}\text { Petiole length } \\
\text { (mm) }\end{array}$} & \multirow{2}{*}{$\begin{array}{c}\text { Root length } \\
(\mathrm{mm})\end{array}$} \\
\hline & & & & Length (mm) & Width (mm) & & \\
\hline \multirow{8}{*}{2 wks } & \multirow{3}{*}{ SD } & +Fe Cu1 & $7.5 \pm 0.6^{\mathrm{a}}$ & $17.6 \pm 1.8^{\mathrm{a}}$ & $18.2 \pm 1.1^{\mathrm{a}}$ & $13.2 \pm 1.6^{\mathrm{b}}$ & $207.2 \pm 66.7^{\mathrm{c}}$ \\
\hline & & $+\mathrm{Fe} \mathrm{Cu} 2000$ & $7.8 \pm 0.5^{\mathrm{a}}$ & $17.3 \pm 1.0^{\mathrm{a}}$ & $17.1 \pm 1.6^{\mathrm{a}}$ & $13.3 \pm 1.5^{\mathrm{b}}$ & $180.9 \pm 38.5^{c}$ \\
\hline & & -Fe Cu2000 & $7.8 \pm 0.5^{\mathrm{a}}$ & $17.2 \pm 2.9^{\mathrm{a}}$ & $18.2 \pm 2.5^{\mathrm{a}}$ & $16.5 \pm 4.1^{\mathrm{b}}$ & $120.4 \pm 27.9^{b}$ \\
\hline & \multirow{3}{*}{ LD } & +Fe Cu1 & $8.3 \pm 0.6^{\mathrm{b}}$ & $21.1 \pm 2.9^{b}$ & $19.0 \pm 2.8^{\mathrm{ab}}$ & $15.1 \pm 4.7^{\mathrm{b}}$ & $264.4 \pm 8.7^{\mathrm{d}}$ \\
\hline & & $+\mathrm{Fe} \mathrm{Cu} 2000$ & $8.8 \pm 1.0^{\mathrm{b}}$ & $22.2 \pm 4.2^{\mathrm{b}}$ & $19.9 \pm 2.0^{\mathrm{ab}}$ & $17.7 \pm 4.4^{\mathrm{bc}}$ & $195.7 \pm 64.4^{\mathrm{c}}$ \\
\hline & & -Fe Cu2000 & $9.2 \pm 0.8^{\mathrm{b}}$ & $24.3 \pm 4.1^{\mathrm{bc}}$ & $22.8 \pm 3.5^{\mathrm{b}}$ & $22.6 \pm 7.8^{\mathrm{c}}$ & $164.0 \pm 84.4^{\mathrm{c}}$ \\
\hline & \multirow{2}{*}{ CL } & $+\mathrm{Fe} \mathrm{Cu} 2000$ & $7.7 \pm 0.6^{\mathrm{a}}$ & $20.5 \pm 1.8^{\mathrm{b}}$ & $22.8 \pm 0.8^{\mathrm{b}}$ & $12.6 \pm 3.8^{\mathrm{ab}}$ & $200.0 \pm 40.5^{c}$ \\
\hline & & -Fe Cu2000 & $8.3 \pm 0.6^{\mathrm{b}}$ & $15.9 \pm 2.1^{\mathrm{a}}$ & $15.8 \pm 3.0^{\mathrm{a}}$ & $9.7 \pm 3.3^{\mathrm{a}}$ & $52.8 \pm 18.0^{\mathrm{a}}$ \\
\hline \multirow{8}{*}{4 wks } & \multirow{3}{*}{ SD } & +Fe Cu1 & $9.3 \pm 0.5^{\mathrm{a}}$ & $22.0 \pm 0.3^{\mathrm{a}}$ & $22.3 \pm 1.2^{\mathrm{b}}$ & $18.8 \pm 2.0^{\mathrm{b}}$ & $209.2 \pm 47.4^{\mathrm{b}}$ \\
\hline & & +Fe Cu2000 & $9.8 \pm 0.5^{\mathrm{a}}$ & $21.7 \pm 3.1^{\mathrm{a}}$ & $22.4 \pm 1.7^{\mathrm{b}}$ & $18.5 \pm 4.6^{\mathrm{b}}$ & $204.3 \pm 39.3^{\mathrm{b}}$ \\
\hline & & -Fe Cu2000 & $9.8 \pm 0.5^{\mathrm{a}}$ & $24.2 \pm 2.3^{\mathrm{ab}}$ & $23.9 \pm 2.5^{\mathrm{b}}$ & $21.3 \pm 4.0^{\mathrm{b}}$ & $219.2 \pm 40.2^{b}$ \\
\hline & \multirow{3}{*}{ LD } & +Fe Cu1 & $10.3 \pm 1.0^{\mathrm{ab}}$ & $31.9 \pm 4.2^{c}$ & $30.3 \pm 3.7^{c}$ & $27.1 \pm 9.6^{\mathrm{bc}}$ & $301.4 \pm 48.2^{\mathrm{C}}$ \\
\hline & & $+\mathrm{Fe} \mathrm{Cu} 2000$ & $11.5 \pm 0.6^{\mathrm{b}}$ & $29.5 \pm 6.6^{\mathrm{bc}}$ & $29.9 \pm 4.4^{\mathrm{c}}$ & $25.3 \pm 5.3^{\mathrm{bc}}$ & $284.3 \pm 55.0^{c}$ \\
\hline & & -Fe Cu2000 & $12.3 \pm 1.0^{\mathrm{bc}}$ & $34.0 \pm 5.0^{c}$ & $31.4 \pm 1.4^{\mathrm{c}}$ & $35.4 \pm 9.3^{c}$ & $182.2 \pm 63.8^{\mathrm{b}}$ \\
\hline & \multirow{2}{*}{ CL } & +Fe Cu2000 & $12.0 \pm 0.0^{\mathrm{bc}}$ & $35.9 \pm 5.3^{c}$ & $32.3 \pm 2.5^{c}$ & $22.2 \pm 5.9^{\mathrm{b}}$ & $208.2 \pm 73.8^{b}$ \\
\hline & & -Fe Cu2000 & $11.3 \pm 0.6^{\mathrm{b}}$ & $21.1 \pm 4.9^{\mathrm{a}}$ & $20.6 \pm 6.6^{\mathrm{ab}}$ & $14.6 \pm 7.4^{\mathrm{a}}$ & $90.3 \pm 6.4^{\mathrm{a}}$ \\
\hline
\end{tabular}

Seedlings were treated with control Cu1 $(0.1 \mu \mathrm{M})$ and excess Cu2000 $(200 \mu \mathrm{M})$ in combination with/without Fe for 2 and 4 weeks at $25^{\circ} \mathrm{C}$ on a rotary shaker at $50 \mathrm{rpm}$ in the incubator, under three different light regimes $\left(121 \mu \mathrm{mol} \cdot \mathrm{m}^{-2} \cdot \mathrm{s}^{-1}\right)$ : short day (SD), $10 \mathrm{~h}$ light - $14 \mathrm{~h} \mathrm{dark}$; long day (LD), $16 \mathrm{~h}$ light -8 h dark: continuous light (CL), 24 h light. -Fe, no addition of Fe; +Fe, with addition of $100 \mu \mathrm{M}$ Fe(III)-EDTA. Data are means and SD of 4 plants. Different letters indicate significant differences between the treatments $(\mathrm{P}<0.05)$ after 2-way ANOVA.

Table 2. Plant development of $H$. albus seedlings after culturing under various $\mathrm{Cu} / \mathrm{Fe}$ supply and light conditions: changes in fresh weight (FW), dry weight (DW) and water content.

\begin{tabular}{|c|c|c|c|c|c|}
\hline \multirow{2}{*}{$\begin{array}{l}\text { Culture } \\
\text { period }\end{array}$} & \multirow{2}{*}{$\begin{array}{c}\text { Light } \\
\text { condition }\end{array}$} & \multirow{2}{*}{$\begin{array}{c}\mathrm{Cu} / \mathrm{Fe} \\
\text { condition }\end{array}$} & \multicolumn{3}{|c|}{ Whole plant } \\
\hline & & & mg FW & mg DW & Water content (\%) \\
\hline \multirow{8}{*}{2 wks } & \multirow{3}{*}{ SD } & +Fe Cu1 & $280 \pm 47^{\mathrm{a}}$ & $14.5 \pm 3.1^{\mathrm{a}}$ & $94.8 \pm 0.3^{\mathrm{a}}$ \\
\hline & & +Fe Cu2000 & $303 \pm 79^{\mathrm{a}}$ & $14.9 \pm 3.4^{\mathrm{a}}$ & $95.1 \pm 0.5^{\mathrm{a}}$ \\
\hline & & -Fe Cu2000 & $326 \pm 131^{\mathrm{a}}$ & $15.9 \pm 5.0^{\mathrm{a}}$ & $95.1 \pm 0.7^{\mathrm{a}}$ \\
\hline & \multirow{3}{*}{ LD } & +Fe Cu1 & $461 \pm 149^{b}$ & $26.9 \pm 5.3^{b}$ & $94.2 \pm 0.8^{\mathrm{a}}$ \\
\hline & & $+\mathrm{Fe} \mathrm{Cu} 2000$ & $668 \pm 330^{\mathrm{b}}$ & $33.5 \pm 11.6^{\mathrm{b}}$ & $95.0 \pm 0.7^{\mathrm{a}}$ \\
\hline & & -Fe Cu2000 & $895 \pm 404^{b}$ & $45.4 \pm 20.4^{\mathrm{b}}$ & $94.9 \pm 0.4^{\mathrm{a}}$ \\
\hline & \multirow{2}{*}{ CL } & +Fe Cu2000 & $576 \pm 102^{\mathrm{b}}$ & $32.5 \pm 4.3^{b}$ & $94.4 \pm 0.2^{\mathrm{a}}$ \\
\hline & & -Fe Cu2000 & $371 \pm 135^{\mathrm{ab}}$ & $32.0 \pm 8.6^{\mathrm{b}}$ & $91.1 \pm 1.2^{\mathrm{b}}$ \\
\hline \multirow{8}{*}{4 wks } & \multirow{3}{*}{ SD } & +Fe Cu1 & $635 \pm 95^{\mathrm{a}}$ & $26.9 \pm 4.3^{\mathrm{a}}$ & $95.8 \pm 0.1^{\mathrm{a}}$ \\
\hline & & +Fe Cu2000 & $730 \pm 262^{\mathrm{a}}$ & $32.8 \pm 1.0^{\mathrm{a}}$ & $95.5 \pm 0.2^{\mathrm{a}}$ \\
\hline & & -Fe Cu2000 & $781 \pm 189^{\mathrm{a}}$ & $34.5 \pm 7.1^{\mathrm{a}}$ & $95.6 \pm 0.3^{\mathrm{a}}$ \\
\hline & \multirow{3}{*}{ LD } & $+\mathrm{Fe} \mathrm{Cu} 1$ & $1644 \pm 702^{\mathrm{b}}$ & $73.9 \pm 25.5^{\mathrm{b}}$ & $95.5 \pm 0.5^{\mathrm{a}}$ \\
\hline & & +Fe Cu2000 & $1978 \pm 794^{\mathrm{b}}$ & $85.4 \pm 29.1^{b}$ & $95.7 \pm 0.4^{\mathrm{a}}$ \\
\hline & & -Fe Cu2000 & $2573 \pm 792^{\mathrm{b}}$ & $121.2 \pm 41.3^{\mathrm{b}}$ & $95.3 \pm 0.1^{\mathrm{a}}$ \\
\hline & \multirow{2}{*}{ CL } & $+\mathrm{Fe} \mathrm{Cu} 2000$ & $2562 \pm 310^{\mathrm{b}}$ & $114.1 \pm 11.3^{\mathrm{b}}$ & $95.5 \pm 0.1^{\mathrm{a}}$ \\
\hline & & -Fe Cu2000 & $1747 \pm 1099^{\mathrm{ab}}$ & $143.7 \pm 67.4^{\mathrm{b}}$ & $91.8 \pm 1.8^{\mathrm{b}}$ \\
\hline
\end{tabular}

Seedlings were treated with control Cu1 $(0.1 \mu \mathrm{M})$ and excess $\mathrm{Cu} 2000(200 \mu \mathrm{M})$ in combination with/without Fe for 2 and 4 weeks at $25^{\circ} \mathrm{C}$ on a rotary shaker at $50 \mathrm{rpm}$ in the incubator, under three different light regimes $\left(121 \mu \mathrm{mol} \cdot \mathrm{m}^{-2} \cdot \mathrm{s}^{-1}\right)$ : short day (SD), $10 \mathrm{~h} \mathrm{light} \mathrm{-} 14 \mathrm{~h} \mathrm{dark}$; long day (LD), $16 \mathrm{~h}$ light - 8 h dark: continuous light (CL), 24 h light. -Fe, no addition of Fe; +Fe, with addition of $100 \mu \mathrm{M}$ Fe(III)-EDTA. Data are means and SD of 4 plants. Different letters indicate significant differences between the treatments $(\mathrm{P}<0.05)$ after 2-way ANOVA 
the overall exposure to light energy (i.e. the product of light intensity and duration) that is critical for the appearance of damage under Fe deficiency. Foyer and Noctor have commented that when light is in excess, or when the electron transport capacity in the chloroplast is limited, electrons can directly reduce molecular oxygen [24]. The continuous production of reactive oxygen species (ROS) in chloroplasts during photosynthesis, in the absence of a fully adequate scavenging mechanism such as Fe superoxide dismutase (FeSOD), must be a potential cause of damage by continuous light [7]. Our results showed that growth inhibition was apparent not only in the leaves but also in the roots, suggesting that the radical scavenging system associated with mitochondrial respiration might be impaired also.

\subsection{Cu Accumulation in Plants under Cu Excess}

The $\mathrm{Cu}$ contents of the $\mathrm{H}$. albus plants cultured under $\mathrm{Cu}$ excess, with or without $\mathrm{Fe}$, in combination with the various illumination conditions described above were analyzed by ICP-OES. Since the $\mathrm{Cu}$ contents of plants supplied with $0.1 \mu \mathrm{M} \mathrm{Cu}$ were below the limit of detection of our assay system (detection limit, $0.2 \mathrm{mg} \cdot \mathrm{L}^{-1}$ ), only data for plants grown under $\mathrm{Cu}$ excess are shown (Figure 2). Expressed on a whole-plant basis, the values for $\mathrm{Cu}$ accumulation in seedlings cultured for 4 weeks were very much greater than in those cultured for 2 weeks. The illumination conditions strongly affected $\mathrm{Cu}$ accumulation. The amounts of $\mathrm{Cu}$ in whole plants cultured under LD were more than 6 times greater than in those cultured under SD. Furthermore, under the same illumination conditions, appreciably more $\mathrm{Cu}$ was accumulated in plants cultured under Fe deficiency than in plants cultured under Fe-replete conditions. Thus, when Fe was deficient, the amount of $\mathrm{Cu}$ reached $740 \pm 92 \mathrm{nmol} \cdot \mathrm{plant}^{-1}$ under LD, declining by a quarter under CL $\left(560 \pm 110 \mathrm{nmol}^{-}\right.$plant $\left.^{-1}\right)$. Under Fe-replete conditions, less Cu was accumulated and no difference was found between LD and CL (419 \pm 122 and $452 \pm 73 \mathrm{nmol} \cdot$ plant $^{-1}$, respectively). Cu was accumulated in both aerial parts and roots; and under Fe-replete conditions, more than half of the $\mathrm{Cu}$ was recovered from the aerial parts (leaf blade, petiole and stem), and the leaf blade was the organ in which the largest proportion of the $\mathrm{Cu}$ was accumulated. Under Fe deficiency, however, $\mathrm{Cu}$ accumulation increased in the roots (Figure 2). Thus, the $\mathrm{Cu}$ contents in the leaves and roots of seedlings cultured for 4 weeks under LD were as follows: under Fe deficiency, $223 \pm 126 \mu \mathrm{g} \cdot \mathrm{g}^{-1} \mathrm{DW}$ and $1220 \pm 184 \mu \mathrm{g} \cdot \mathrm{g}^{-1} \mathrm{DW}$, respectively, and under Fe-replete conditions, $208 \pm 86 \mu \mathrm{g} \cdot \mathrm{g}^{-1} \mathrm{DW}$ and $415 \pm 121 \mu \mathrm{g} \cdot \mathrm{g}^{-1} \mathrm{DW}$, respectively. Fe availability therefore had little or no effect on leaf $\mathrm{Cu}$ content; in contrast, under Fe deficiency, root $\mathrm{Cu}$ content was about five times higher than leaf $\mathrm{Cu}$ content, whereas under Fe-replete conditions it was only about twice as high.

These results indicated that the amounts of $\mathrm{Cu}$ translocated from the roots to the aerial parts were similar between the LD and the CL conditions, regardless of Fe availability; however, when Fe was deficient, and under given illumination conditions, more $\mathrm{Cu}$ was accumulated in the roots than in the aerial parts. Since most of the Fe was accumulated in the roots, as discussed below (Figure 3), Cu might presumably occupy sites that are vacated under conditions of Fe deficiency. The $\mathrm{Cu}$ concentration in the leaves of seedlings treated for 4 weeks under LD was greater than $200 \mu \mathrm{g} \cdot \mathrm{g}^{-1} \mathrm{DW}$, and this value is toxic to $\mathrm{Cu}$ non-tolerant plants: typically, Cu toxicity begins to be observed above $20 \mu \mathrm{g} \cdot \mathrm{g}^{-1} \mathrm{DW}$ [5]. Although concentrations of Cu higher than $200 \mu \mathrm{M}$ have been used in some previously reported studies [25]-[28], in the work reported here we did not treat seedlings with more than $200 \mu \mathrm{M} \mathrm{Cu}$ so as to avoid precipitation by interaction with other ions, and for not more than 4 weeks because of the limitations of the medium and space in a seedling growth container. Because we used only rosette-stage seedlings, which could be grown on to flowering stage, it might be possible to achieve higher levels of $\mathrm{Cu}$ accumulation if $\mathrm{H}$. albus plants were treated with much higher levels of $\mathrm{Cu}$ in the soil, and for longer periods. Lycopersicon esculentum plants accumulated more $\mathrm{Cu}$ in in vivo-grown leaves than in vitro-grown leaves [10]. In Brassica napus plants, older leaves accumulated $\mathrm{Cu}$ to a greater extent than younger leaves [29]. We have also found a similar tendency in H. albus seedlings (data not shown).

\section{3. $\mathrm{Cu}$ and Fe Allocations at the Organ and Cellular Levels}

The high levels of incorporation of $\mathrm{Cu}$ into $\mathrm{H}$. albus seedlings raised the question of the sites of accumulation of $\mathrm{Cu}$ at the subcellular level. Seedlings exposed to excess $\mathrm{Cu}$ and Fe-replete conditions under LD for 4 weeks were therefore first divided into aerial parts and roots, and then their homogenates were divided into four fractions by filtration and centrifugation, according to a previous report [15], with some modifications; the four fractions comprised a cell-wall fraction, a fraction containing nuclei and plastids, a mitochondrial fraction and, lastly, a soluble fraction including vacuoles and cytosol. Both the $\mathrm{Cu}$ contents and, for comparison, the Fe contents 


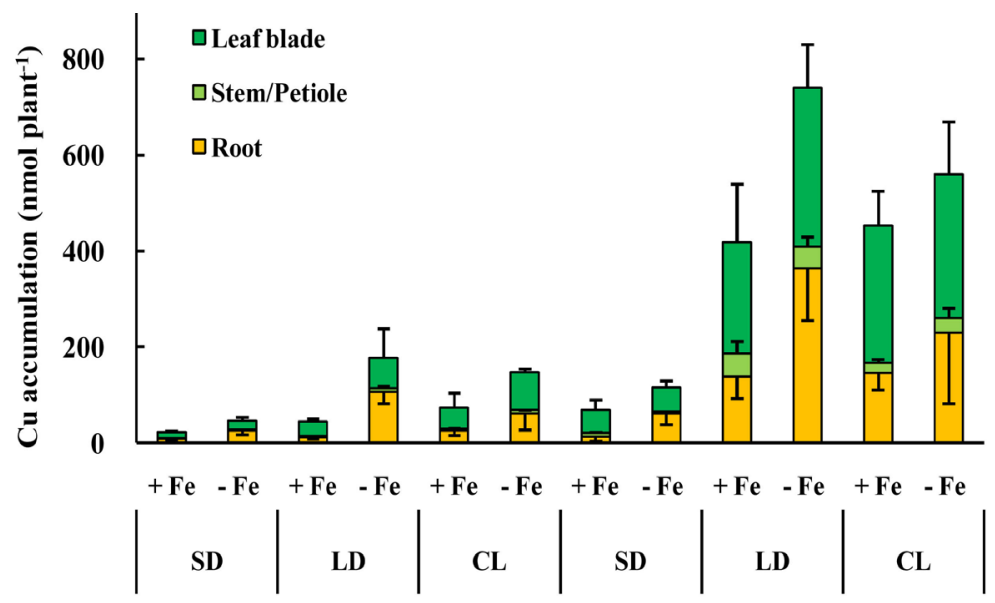

Figure 2. $\mathrm{Cu}$ distribution in various organs of $H$. albus plants. Seedlings were treated with $\mathrm{Cu}$ excess $(200 \mu \mathrm{M})$ in combination with/without Fe for 2 and 4 weeks at $25^{\circ} \mathrm{C}$ on a rotary shaker at $50 \mathrm{rpm}$ in the incubator, under three different light regimes $\left(121 \mu \mathrm{mol} \cdot \mathrm{m}^{-2} \cdot \mathrm{s}^{-1}\right)$ : short day (SD), $10 \mathrm{~h}$ light - $14 \mathrm{~h}$ dark; long day (LD), $16 \mathrm{~h}$ light $-8 \mathrm{~h}$ dark: continuous light (CL), 24 h light. -Fe, no addition of Fe; +Fe, with addition of $100 \mu \mathrm{M}$ Fe(III)-EDTA. Data are means and sd of 4 samples.
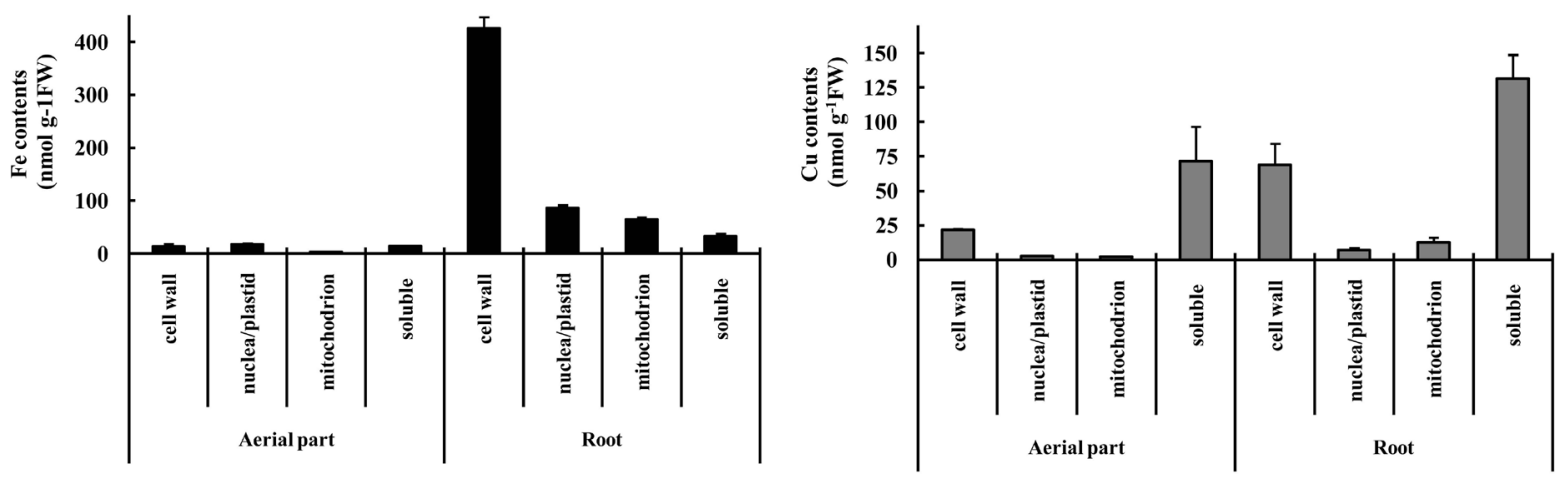

Figure 3. $\mathrm{Cu}$ and Fe allocations in various fractions from aerial parts and roots. Seedlings supplied with $\mathrm{Cu}$ excess $(200 \mu \mathrm{M})$ together with Fe $(100 \mu \mathrm{M})$ were cultured under long day (LD) condition for 4 weeks. Freshly harvested tissues (ca. 2 g) were ground in $50 \mathrm{mM}$ Tris- $\mathrm{HCl}$ buffer $(\mathrm{pH} 7.5)$ containing $250 \mathrm{mM}$ sucrose and $10 \mathrm{mM}$ DTT at $4^{\circ} \mathrm{C}$ and then filtered through nylon mesh $(84 \mathrm{~mm})$ in vacuo. Cell wall was recovered on the filter. The filtrate was centrifuged at $880 \times \mathrm{g}$, followed by 21,880 × g: the pellets were denoted as "nucleus and plastids fraction" and "mitochondrial fraction", respectively, and the rest of the solute as "soluble fraction". Experiments were repeated three times and the average and standard deviation are given.

of fractions were analyzed. The results confirmed that $\mathrm{Cu}$ was present both in the aerial parts and in the roots (Figure 3); in both parts of the plants, the soluble fraction contained the largest proportion of the $\mathrm{Cu}$ ( $73 \%$ and $60 \%$, respectively), followed by the cell-wall fraction (22\% and $31 \%$, respectively). The remaining $\mathrm{Cu}$ was found in the nuclei-plus-plastids and mitochondrial fractions. In the case of Fe, the roots contained 13 times more Fe than the aerial parts (on a nmol.g ${ }^{-1} \mathrm{FW}$ basis); thus, in the roots, the cell-wall fraction contained the largest proportion (70\%), followed by the nuclei-plus-plastids fraction (14\%) and the mitochondrial fraction (11\%) (Figure 3).

The most common cellular mechanisms of $\mathrm{Cu}$ tolerance are binding of the metal ion to the cell wall, allocation into vacuoles and incorporation into cellular components such as proteins and phenolics [30]. In Daucus carota [31], most of the $\mathrm{Cu}$ was found to be sequestered in the cell wall. Wang and Liu [32] also concluded from their results that plants lessen the toxicity of heavy metals by accumulating them in the cell wall. Similarly, Bechmeria nivea root cells accumulated around $50 \%$ of their total cadmium (Cd) in the cell wall, followed by $37 \%$ in the soluble fraction [15]. Our results that Cu accumulation occurred mainly in the soluble and cell-wall fractions in both the aerial parts and roots of $H$. albus are consistent with the above-mentioned reports. In the case of the soluble fraction, the vacuoles must be the main site of sequestration acting to prevent cytosolic $\mathrm{Cu}$ toxicity [33]. 


\subsection{Effects of $\mathrm{Cu}$ and Fe Levels on the Accumulation of Other Minerals}

Treatment of $H$. albus seedlings with excess $\mathrm{Cu}$ resulted in high levels of $\mathrm{Cu}$ accumulation and, under Fe deficiency, more $\mathrm{Cu}$ was accumulated in the roots (Figure 2, Figure 3). To understand the effects of $\mathrm{Cu} / \mathrm{Fe}$ levels on the accumulation of other minerals, divalent mineral cations such as $\mathrm{Ca}, \mathrm{Mg}, \mathrm{Mn}$ and $\mathrm{Zn}$ were also analyzed in seedlings cultured for 4 weeks under LD (Figure 4). Under Fe-replete conditions, Cu excess did not affect the accumulation of any of these ions. On the other hand, under Fe deficiency, the Ca content was apparently increased, whereas the Mn content was significantly decreased, though only in the roots. To examine whether the decrease in Mn was an important cause of the damage resulting from the combination of $\mathrm{Cu}$ excess and $\mathrm{Fe}$ deficiency, we also determined (in place of Fe deficiency) the effects on growth and $\mathrm{Cu}$ accumulation of Mn deficiency (removal of $\mathrm{Mn}$ completely from the culture medium) in combination with $\mathrm{Cu}$ excess $(200 \mu \mathrm{M})$ for 3 weeks under LD. The results showed that leaf chlorosis was observed, although $\mathrm{Cu}$ accumulation was also promoted (data not shown).

A range of effects on mineral accumulation in Cu-treated plants have been reported. In bean plants, excess $\mathrm{Cu}$ (4 and $15 \mu \mathrm{M}$ ) induced Fe deficiency, resulting in decreased leaf chlorophyll [21], and in Cu-tolerant Commelina communis, $100 \mu \mathrm{M} \mathrm{Cu}$ inhibited Fe, Mn and $\mathrm{Zn}$ accumulation significantly [34]. On the other hand, in roots of Elsholtzia argyi, the concentrations of $\mathrm{K}, \mathrm{Ca}, \mathrm{Mg}, \mathrm{Mn}$, and $\mathrm{Zn}$ were not affected, or were even increased, in a Cu-tolerant ecotype [35]. In the work reported here, H. albus plants were presumably able to thrive under excess $\mathrm{Cu}$ because the accumulation of minerals, including $\mathrm{Ca}, \mathrm{Mg}, \mathrm{Mn}$ and $\mathrm{Zn}$, was not affected significantly, provided that sufficient Fe was available (Figure 3). However, Mn contents decreased in the roots subjected to $\mathrm{Cu}$ excess and Fe deficiency in combination, even under LD. These results suggested that Mn deficiency induced by $\mathrm{Cu}$ excess in the presence of Fe deficiency was a possible contributory cause of the observed growth damage and reduced water content that occurred under CL (Table 1, Table 2).

\section{Conclusions}

Hyoscyamus spp. have a folkloric history as poisonous plants and they contain hyoscyamine as a major tropane alkaloid used in medicine [36]. In this paper, we have presented evidence indicating that $H$. albus seedlings are tolerant of $\mathrm{Cu}$ present in excess. Furthermore, excess $\mathrm{Cu}$ was able to compensate for Fe deficiency, depending on the light conditions. Continuous light inhibited this effect, probably as a result of the induction of Mn deficiency.

Although many plants displaying Cu tolerance have been reported [25] [37]-[39], this is the first report relating to the medicinal plant, $H$. albus. These interesting findings suggest the novel possibility of utilizing this plant both as a source of medicinal compounds and as a $\mathrm{Cu}$ accumulator. Since a high accumulation of $\mathrm{Cu}$ renders

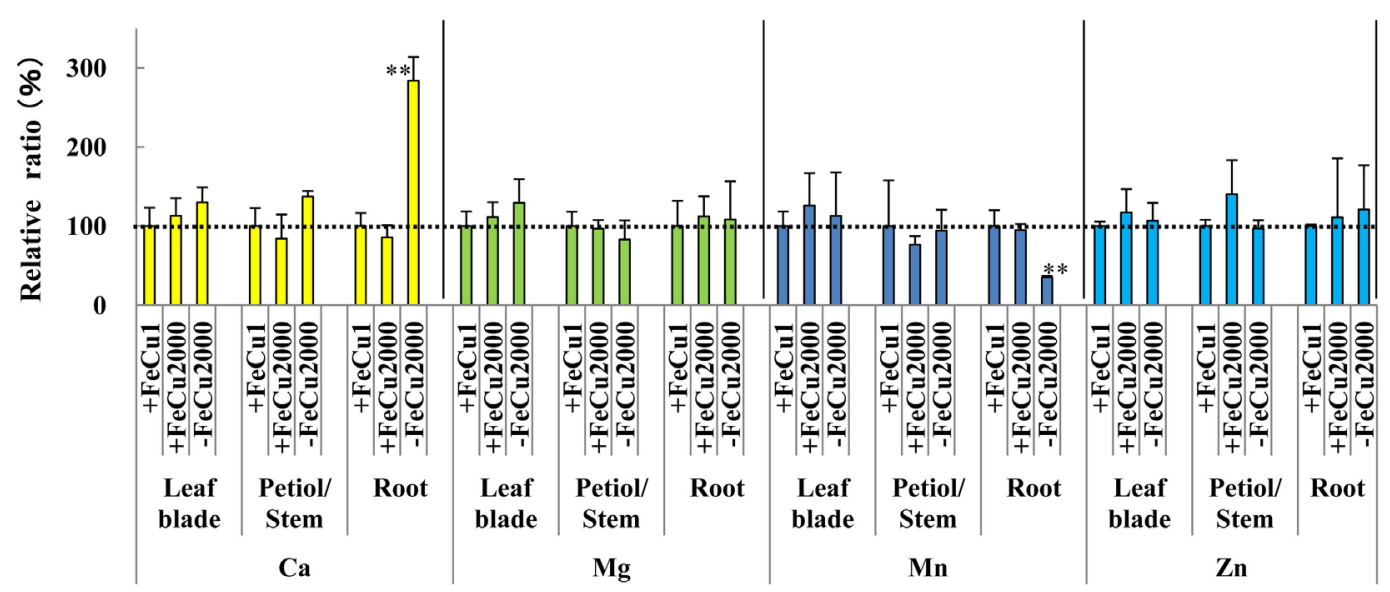

Figure 4. Minerals (Ca, Mg, Mn and $\mathrm{Zn}$ ) contents in the various organs. Seedlings were subjected to different $\mathrm{Cu} / \mathrm{Fe}$ concentrations and cultured under long day (LD) conditions for 4 weeks. +Fe, with $100 \mu \mathrm{M} \mathrm{Fe}(\mathrm{III})$-EDTA; -Fe, without Fe; $\mathrm{Cu} 1,0.1 \mu \mathrm{M} \mathrm{CuSO}_{4}$; Cu2000, $200 \mu \mathrm{M} \mathrm{CuSO}_{4}$. Control (+Fe Cu1) is expressed as $100 \%$. Others are expressed as relative values. Data are means and sd of 4 samples. Data are analyzed by ANOVA and Student $t$-test. ${ }^{* *}$ Reveals significant differences at the levels of $\mathrm{P}<0.01$ compared with control. 
plants toxic and non-edible, $H$. albus, which is toxic on account of its alkaloid content, may become additionally toxic when it absorbs $\mathrm{Cu}$. Whereas hyoscyamine is a feeding deterrent for vertebrates as well as several insects [40], Cu has a fungicidal effect [41]; therefore, by virtue of complementary mechanisms, H. albus plants may be equipped to protect themselves from attack by a variety of organisms and to thrive on Cu-polluted soils. In such areas, the cultivation of edible crop plants such as vegetables and cereals is not feasible even for phytoremediation, due to accidental and intentional distribution as foods. If $H$. albus plants were to be cultivated in a $\mathrm{Cu}$-polluted area, both hyoscyamine as a drug and $\mathrm{Cu}$ as a useful metal could be recovered from the harvested plants by extraction: alkaloids would be extracted by organic solvent and $\mathrm{Cu}$ would remain in the mineral fraction. Recovery of $\mathrm{Cu}$ in this way from heavily-polluted areas could provide an additional source of income for farmers. Further study is now needed of the cultivation of medicinal $H$. albus plants in the field as both $\mathrm{Cu}$ scavengers and alkaloid producers.

\section{Acknowledgements}

We thank Dr. Laiq ur Rahman (CIMAP, India) for kind supply of $H$. albus seeds and Dr. Ataru Higa for his assistance during this work. We also appreciate the English language editing by Dr. Nicholas Walton (Norwich, UK). This work was supported by a Grant-in-Aid (C, 24580479) from the Japan Society for the Promotion of Science.

\section{References}

[1] Evans, W. (1996) Trease and Evans’ Pharmacognosy. WB Saunders Company Ltd., London.

[2] Higa, A., Miyamoto, E., Rahman, L. and Kitamura, Y. (2008) Root Tip-Dependent, Active Riboflavin Secretion by Hyoscyamus albus Hairy Roots under Iron Deficiency. Plant Physiology and Biochemistry, 46, 452-460. http://dx.doi.org/10.1016/j.plaphy.2008.01.004

[3] Higa, A., Mori, Y. and Kitamura, Y. (2010) Iron Deficiency Induces Changes in Riboflavin Secretion and the Mitochondrial Electron Transport Chain in Hairy Roots of Hyoscyamus albus. Journal of Plant Physiology, 167, 870-878. http://dx.doi.org/10.1016/j.jplph.2010.01.011

[4] FAO Repository (1998) Lecture Notes on the Major Soils of the World. http://www.fao.org/docrep/003/Y1899E/y1899e09.htm\#TopOfPage

[5] Burkhead, J.L., Reynolds, K.A., Abdel-Ghany, S.E., Cohu, C.M. and Pilon, M. (2009) Copper Homeostasis. New Phytologist, 182, 799-816. http://dx.doi.org/10.1111/j.1469-8137.2009.02846.X

[6] Masarovicǒvá, E., Králǒvá, K. and Kummerova, M. (2010) Principles of Classification of Medicinal Plants as Hyperaccumulators or Excluders. Acta Physiologiae Plantarum, 32, 7.

[7] Ravet, K. and Pilon, M. (2013) Copper and Iron Homeostasis in Plants: The Challenges of Oxidative Stress. Antioxidants \& Redox Signaling, 19, 919-932. http://dx.doi.org/10.1089/ars.2012.5084

[8] Puig, S., Andrés-Colás, N., García-Molina, A. and Peñarrubia, L. (2007) Copper and Iron Homeostasis in Arabidopsis: Responses to Metal Deficiencies, Interactions and Biotechnological Applications. Plant, Cell \& Environment, 30, 271290. http://dx.doi.org/10.1111/j.1365-3040.2007.01642.x

[9] Waters, B.M. and Armbrust, L.C. (2013) Optimal Copper Supply Is Required for Normal Plant Iron Deficiency Responses. Plant Signaling \& Behavior, 8, 1-5. http://dx.doi.org/10.4161/psb.26611

[10] Khan, F., Younas, A., Shaheeen, S., Yousaf, Z., Gilani, K., Munawar, M., Sia, Z. K., Ahmad, M. and Zafar, M. (2011) Scavenging Evaluation of Copper and Cadmium during in Vivo and in Vitro Growth of Lycopersicon esculentum Mill. by Atomic Absorption Spectroscopy. Journal of Medicinal Plants Research, 5, 6468-6472.

[11] Küpper, H., Götz, B., Mijovilovich, A., Küpper, F.C. and Meyer-Klaucke, W. (2009) Complexation and Toxicity of Copper in Higher Plants. I. Characterization of Copper Accumulation, Speciation, and Toxicity in Crassula helmsii as a New Copper Accumulator. Plant Physiology, 151, 702-714. http://dx.doi.org/10.1104/pp.109.139717

[12] Faucon, M.P., Shutcha, M.N. and Meerts, P. (2007) Revisiting Copper and Cobalt Concentrations in Supposed Hyperaccumulators from SC Africa: Influence of Washing and Metal Concentrations in Soil. Plant and Soil, 301, 29-36. http://dx.doi.org/10.1007/s11104-007-9405-3

[13] Murashige, T. and Skoog, F. (1962) A Revised Medium for Rapid Growth and Bioassay with Tobacco Tissue Cultures. Physiologia Plantarum, 15, 473-497. http://dx.doi.org/10.1111/j.1399-3054.1962.tb08052.x

[14] Gamborg, O.L., Miller, R.A. and Ojima, K. (1968) Nutrient Requirements of Suspension Cultures of Soybean Root Cells. Experimental Cell Research, 50, 151-158. http://dx.doi.org/10.1016/0014-4827(68)90403-5 
[15] Wang, X., Liu, Y., Zeng, G., Chai, L., Song, X., Min, Z. and Xiao, X. (2008) Subcellular Distribution and Chemical Forms of Cadmium in Bechmeria nivea L. Gaud. Environmental and Experimental Botany, 62, 389-395. http://dx.doi.org/10.1016/j.envexpbot.2007.10.014

[16] López-Millán, A.F., Morales, F., Andaluz, S., Gogorcena, Y., Abadía, A., De Las Rivas, J. and Abadía, J. (2000) Responses of Sugar Beet Roots to Iron Deficiency. Changes in Carbon Assimilation and Oxygen Use. Plant Physiology, 124, 885-898. http://dx.doi.org/10.1104/pp.124.2.885

[17] Landsberg, E.C. (1986) Function of Rhizodermal Transfer Cells in the Fe Stress Response Mechanism of Capsicum annuum L. Plant Physiology, 82, 511-517. http://dx.doi.org/10.1104/pp.82.2.511

[18] Rellán-Álvarez, R., El-Jendoubi, H., Wohlgemuth, G., Abadía, A., Fiehn, O., Abadía, J. and Álvarez-Fernández, A. (2011) Metabolite Profile Changes in Xylem Sap and Leaf Extracts of Strategy I Plants in Response to Iron Deficiency and Resupply. Frontiers in Plant Science, 2, 18. http://dx.doi.org/10.3389/fpls.2011.00066

[19] Rombolà, A.D. and Tagliavini, M. (2006) Iron Nutrition of Fruit Tree Crops. In: Barton, L.L. and Abadía, J., Eds., Nutrition in Plants and Rhizospheric Microorganisms, Springer, Berlin, 61-83. http://dx.doi.org/10.1007/1-4020-4743-6_3

[20] Martins, L.L. and Mourato, M.P. (2006) Effect of Excess Copper on Tomato Plants: Growth Parameters, Enzyme Activities, Chlorophyll, and Mineral Content. Journal of Plant Nutrition, 29, 2179-2198. http://dx.doi.org/10.1080/01904160600972845

[21] Pätsikkä, E., Kairavuo, M., Sersen, F., Aro, E.M. and Tyystjärvi, E. (2002) Excess Copper Predisposes Photosystem II to Photoinhibition in Vivo by Outcompeting Iron and Causing Decrease in Leaf Chlorophyll. Plant Physiology, 129, 1359-1367. http://dx.doi.org/10.1104/pp.004788

[22] Potters, G., Pasternak, T.P., Guisez, Y., Palme, K.J. and Jansen, M.A. (2007) Stress-Induced Morphogenic Responses: Growing out of Trouble? Trends in Plant Science, 12, 98-105. http://dx.doi.org/10.1016/j.tplants.2007.01.004

[23] Lequeux, H., Hermans, C., Lutts, S. and Verbruggen, N. (2010) Response to Copper Excess in Arabidopsis thaliana: Impact on the Root System Architecture, Hormone Distribution, Lignin Accumulation and Mineral Profile. Plant Physiology and Biochemistry, 48, 673-682. http://dx.doi.org/10.1016/j.plaphy.2010.05.005

[24] Foyer, C.H. and Noctor, G. (2009) Redox Regulation in Photosynthetic Organisms: Signaling, Acclimation, and Practical Implications. Antioxidants and Redox Signaling, 11, 861-905. http://dx.doi.org/10.1089/ars.2008.2177

[25] Zappala, M.N., Ellzey, J.T., Bader, J., Peralta-Videa, J.R. and Gardea-Torresdey, J. (2013) Prosopis pubescens (Screw Bean Mesquite) Seedlings Are Hyperaccumulators of Copper. Archives of Environmental Contamination and Toxicology, 65, 212-223. http://dx.doi.org/10.1007/s00244-013-9904-6

[26] Valderrama, A., Tapia, J., Peñailillo, P. and Carvajal, D.E. (2013) Water Phytoremediation of Cadmium and Copper Using Azolla filiculoides Lam. in a Hydroponic System. Water and Environment Journal, 27, 293-300.

[27] Dhir, B. and Srivastava, S. (2013) Heavy Metal Tolerance in Metal Hyperaccumulator Plant, Salvinia natans. Bulletin of Environmental Contamination and Toxicology, 90, 720-724. http://dx.doi.org/10.1007/s00128-013-0988-5

[28] Yang, M.J., Yang, X.E. and Römheld, V. (2002) Growth and Nutrient Composition of Elsholtzia splendens Nakai under Copper Toxicity. Journal of Plant Nutrition, 25, 1359-1375. http://dx.doi.org/10.1081/PLN-120005395

[29] Khurana, N., Singh, M.V. and Chatterjee, C. (2006) Copper Stress Alters Physiology and Deteriorates Seed Quality of Rapeseed. Journal of Plant Nutrition, 29, 93-101. http://dx.doi.org/10.1080/01904160500416489

[30] Oliva, S.R., Mingorance, M.D., Valdés, B. and Leidi, E.O. (2010) Uptake, Localisation and Physiological Changes in Response to Copper Excess in Erica andevalensis. Plant and Soil, 328, 411-420. http://dx.doi.org/10.1007/s11104-009-0121-z

[31] Ke, W., Xiong, Z., Xie, M. and Luo, Q. (2007) Accumulation, Subcellular Localization and Ecophysiological Responses to Copper Stress in two Daucus carota L. Populations. Plant and Soil, 292, 291-304. http://dx.doi.org/10.1007/s11104-007-9229-1

[32] Wang, X.W. and Liu, Z.F. (2013) The Subcellular Distributions of Cadmium, Chromium, Copper, Plumbum and Zinc in Hyperaccumulator and Accumulator. Advanced Materials Research, 726-731, 2434-2437.

[33] Bernal, M., Ramiro, M.V., Casesb, R., Picorel, R. and Yruela, I. (2006) Excess Copper Effect on Growth, Chloroplast Ultrastructure, Oxygen-Evolution Activity and Chlorophyll Fluorescence in Glycine max Cell Suspensions. Physiologia Plantarum, 127, 312-325. http://dx.doi.org/10.1111/j.1399-3054.2006.00641.X

[34] Shi, J., Yuan, X., Chen, X., Wu, B., Huang, Y. and Chen, Y. (2011) Copper Uptake and Its Effect on Metal Distribution in Root Growth Zones of Commelina communis Revealed by SRXRF. Biological Trace Element Research, 141, 294-304. http://dx.doi.org/10.1007/s12011-010-8710-5

[35] Jiang, L.Y., Yang, X.E., Shi, W.Y., Ye, Z.Q. and He, Z.L. (2004) Copper Uptake and Tolerance in Two Contrasting Ecotypes of Elsholtzia argyi. Journal of Plant Nutrition, 27, 2067-2083. http://dx.doi.org/10.1081/PLN-200034635 
[36] Seigler, D.S. (2002) Plant Secondary Metabolism. Kluwer Academic Publishers, Dordrecht.

[37] Chipeng, F.K., Hermans, C., Colinet, G., Faucon, M.P., Ngongo, M., Meerts, P. and Verbruggen, N. (2010) Copper Tolerance in the Cuprophyte Haumaniastrum katangense (S. Moore) P.A. Duvign. \& Plancke. Plant and Soil, 328, 235-244. http://dx.doi.org/10.1007/s11104-009-0105-z

[38] Ghaderian, S.M. and Ravandi, A.A.G. (2012) Accumulation of Copper and Other Heavy Metals by Plants Growing on Sarcheshmeh Copper Mining Area, Iran. Journal of Geochemical Exploration, 123, 25-32. http://dx.doi.org/10.1016/j.gexplo.2012.06.022

[39] Song, J., Zhao, F.J., Luo, Y.M., McGrath, S.P. and Zhang, H. (2004) Copper Uptake by Elsholtzia splendens and Silene vulgaris and Assessment of Copper Phytoavailability in Contaminated Soils. Environmental Pollution, 128, $307-$ 315. http://dx.doi.org/10.1016/j.envpol.2003.09.019

[40] Wink, M. (1993) Allelochemical Properties or the Raison D'être of Alkaloids. The Alkaloids, 43, 1-118.

[41] Somers, E. (1963) The Uptake of Copper by Fungal Cells. Annals of Applied Biology, 51, 425-437. http://dx.doi.org/10.1111/j.1744-7348.1963.tb03710.x 
Scientific Research Publishing (SCIRP) is one of the largest Open Access journal publishers. It is currently publishing more than 200 open access, online, peer-reviewed journals covering a wide range of academic disciplines. SCIRP serves the worldwide academic communities and contributes to the progress and application of science with its publication.

Other selected journals from SCIRP are listed as below. Submit your manuscript to us via either submit@scirp.org or Online Submission Portal.
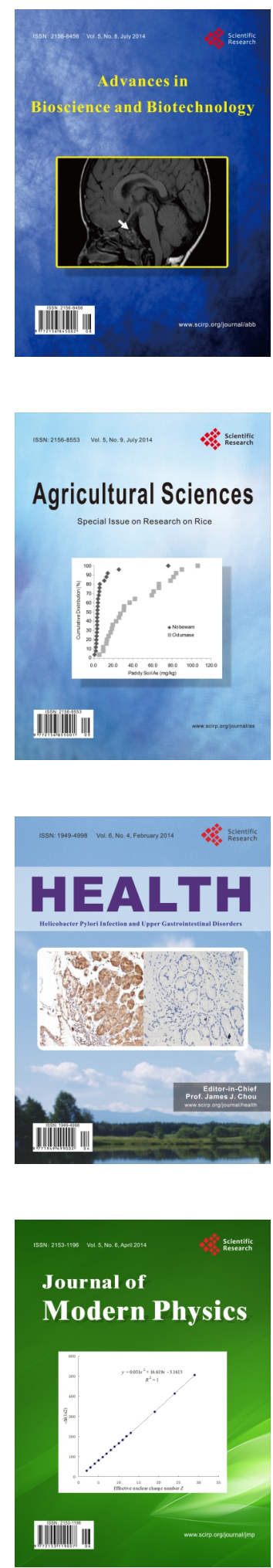
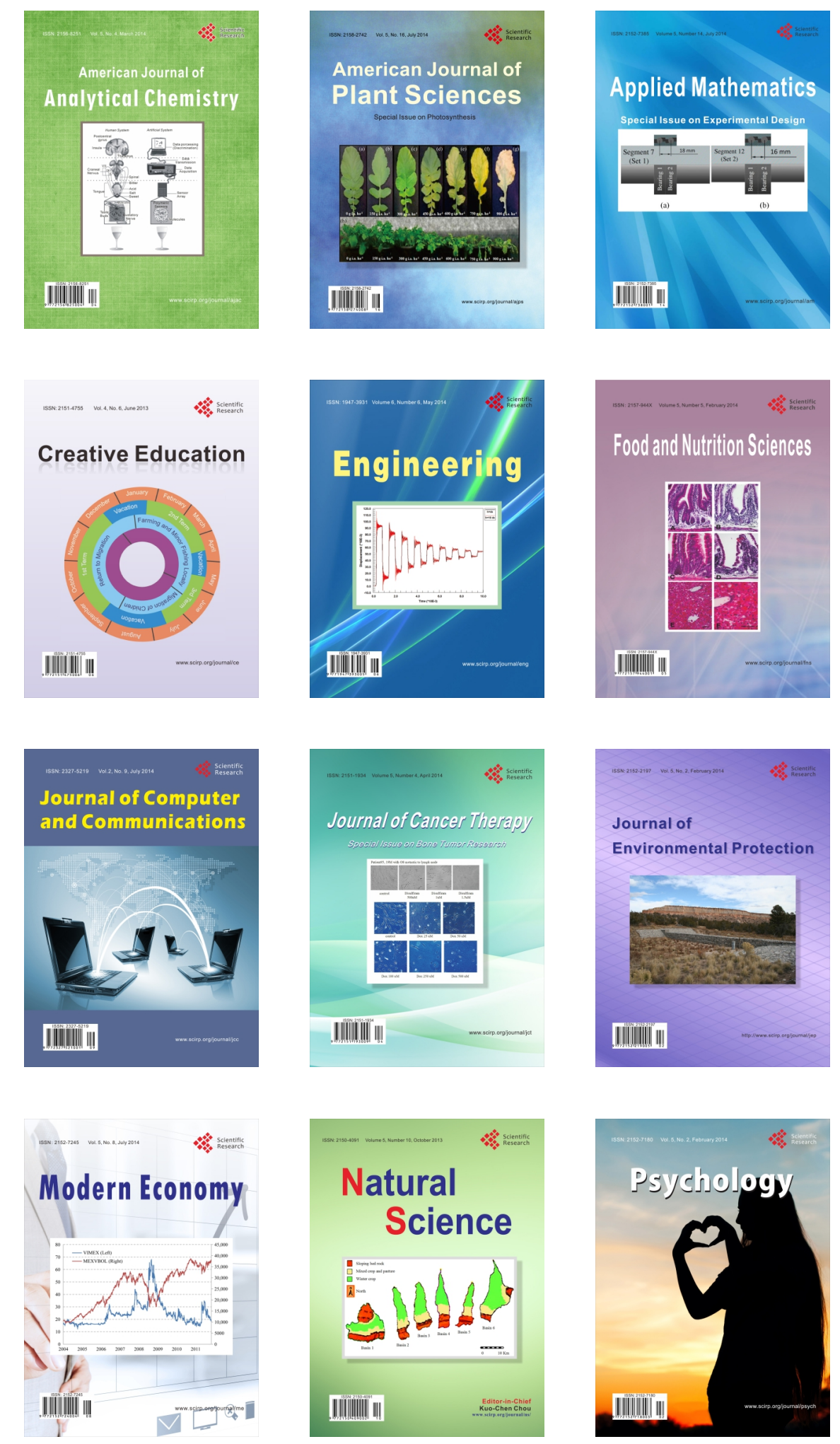